\title{
Mutluluk Potansiyeli ve Ölçülmesi
}

\author{
DOI: 10.26466/opus.657215 \\ $*$

\section{Hasan Bacanl1 ${ }^{*}$ - Ayşe Sibel Demirtaş ${ }^{* *}$} \\ * Prof. Dr., Fatih Sultan Mehmet Vakıf Üniversitesi, Eğitim Fakültesi, İstanbul/Türkiye \\ E-Posta: hasan.bacanli@gmail.com ORCID: 0000-0002-2125-0856 \\ ** Dr. Öğr. Üyesi, Alanya Alaaddin Keykubat Üniversitesi, Eğitim Fakültesi, Antalya/Türkiye \\ E-Posta: asibeldemirtas@gmail.com \\ ORCID: 0009-0001-7793-9583
}

\section{Öz}

Bu araştırmanın konusunu oluşturan "mutluluk potansiyeli", mutluluk düzeyinin değiş̧kenliğine (durumluk mutluluk) odakl olan ve mutluluk yaratma ihtimali ile ilgilenen görüşe dayanır ve kişinin içinde bulunduğ durumdan doyum sağlamasını, sevinç duymasını ifade eder. Bu çalışmanın amacı, bireylerin belirledikleri bir duruma ilişkin mutlu olabilme potansiyellerini belirlemek üzere bir ölçek geliştirmektir. Mutluluk Potansiyeli Ölçeği, 11 maddeden oluşan Likert tipi bir ölçektir. Ölçekte; beklenti, bilgi ve haz olmak üzere 3 alt boyut bulunmaktadır. Geçerlik ve güvenirlik çalışmaları için 306 katılımcıdan veri toplanmıştır. Önerilen 3 faktörlü yapı için Mutluluk Potansiyeli Ölçeği'nin yapı geçerliği, 278 katılımcıdan (\%63'ü kadın, \%36'sı erkek) elde edilen veriler üzerinden temel bileşenler analizi ile saptanmıştır. Katılımcıların yaş ortalaması 31.97'dir ( $S D=10.28)$. Analiz sonucunda maddelerin üç faktörde toplandı̆̆ı ve Mutluluk Potansiyeli Ölçeğgi'ne ait varyansın \% 64.86'sinı açıkladığı görülmüştür. Ölçeğin Cronbach alfa güvenirlik katsayısı, beklenti alt boyutu (3 madde) için .65, bilgi alt boyutu (3 madde) için .64, haz (davranış, ifade) alt boyutu (5 madde) için .88, ve tümü için .86 olarak hesaplanmıştır. Yapılan analizler sonucunda, bireylerin mutluluk potansiyellerini belirlemek için geliştirilen ölçme aracının geçerli ve güvenilir olduğu sonucuna varılmıştır.

Anahtar Kelimeler: mutluluk, mutluluk potansiyeli, pozitif psikoloji 


\title{
The Potential for Happiness and Its Measurement
}

\begin{abstract}
The potential for happiness which is the subject matter of this research, is based on the perspective that is focused on the variability of happiness level (state-happiness) and related to the possibility of creating happiness and it represents the satisfaction of the person in the situation. The purpose of the current study is to develop a scale in order to assess the potential for happiness of individuals related to the situation they have identified. The Happiness for Potential Scale is a Likert-type scale consisting of 11 items. The scale has three factors: expectation, knowledge and pleasure. To conduct the validity and reliability study of the scale, the data were collected from 306 participants. The analyses were conducted with 278 participants (63\% females and $36 \%$ males) after missing observations and outliers were excluded from the data set. The participants' mean age was 31.97, SD $=10.28$. The results showed that the items were accumulated under three factors and explained $64.86 \%$ of the variance in The Potential for Happiness Scale. Cronbach's alpha coefficient was calculated as .65 for expectation factor (3 items), .64 for knowledge factor (3 items) and .88 for pleasure (expression) factor and .86 for the total scale. Based on the findings from the analyses, it could be concluded that the scale which was developed in order to determine the potential for happiness of individuals is a valid and reliable measurement tool.
\end{abstract}

Keywords: Happiness, potential for happiness, positive psychology 


\section{Giriş}

Pozitif duygular ve pozitif kişilik özellikleri ile ilgili araştırmaları temel alan Pozitif Psikoloji yaklaşımı, bilimsel araştırmalar (toplumsal düzeyde) ve bireysel çabaların uygulamaya konması yoluyla (bireysel düzeyde) bireylerin anlamlı yaşam deneyimleri yaratmalarını teşvik eden özelliklerin geliştirilebileceği fikrine dayanmaktadır (Seligman, 2002; Seligman, Steen, Park ve Peterson, 2005; Sheldon ve Lucas, 2016). Pozitif psikoloji yaklaşımının ortaya çkışından bu yana en fazla araştırılan konulardan birisi mutluluk olmuştur. Pozitif psikolojinin ortaya çıkışı din, felsefe, ekonomi ve diğer pek çok alanın mutlulukla ilgili yanıt aradığı soruları yeniden gündeme getirmiştir: "Mutluluk nedir?", "Mutluluğa nasıl ulaşabiliriz?", "Mutluluğa ulaştıktan sonra onu nasıl koruyabiliriz?" (DeHaan ve Ryan, 2014). Alan yazında mutluluğun tanımına ilişkin geniş bir çeşitlilik vardır. Örneğin, Veenhoven' a göre (1997) mutluluk, bir kişinin yaşamını bütünüyle değerlendirilmesine ilişkin zihinsel durumudur. Argyle ve Crossland (1987) mutluluğu, (1) pozitif duyguların sıklığı ve derecesi, (2) belirli bir zaman dilimi içindeki ortalama doyum düzeyi ve (3) depresyon ve anksiyete gibi olumsuz duyguların yokluğu olmak üzere üç unsuru içerecek şekilde kavramsallaştırmışlardır.

Diğer yandan bazı araştırmacılar mutluluğu hedonik ya da eudaimonik olarak sınıflandırmaktadırlar. Bu yaklaşımlar büyük ölçüde sırasıyla Yunan filozofları Aristippus ve Aristotle'a atfedilmektedir. Hedonik iyi oluş, keyif verici duyguların ve ruh durumlarının sık yaşandığı, negatif duyguların ve ruh durumlarının nadiren yaşandığı deneyim ve yüksek düzeyde yaşam doyumu olarak tanımlanmaktadır (Diener, 1984). Hedonik görüşü benimseyen psikologlar, zihnin ve bedenin tercihlerini ve zevklerini içeren geniş bir hedonizm anlayışına odaklanmışlardır (Kubovy, 1999). Hedonik psikologlar arasındaki baskın görüş, mutluluğun öznel mutluluktan oluşması ve yaşamın iyi / kötü unsurları hakkındaki tüm yargıları içermek üzere geniş bir şekilde yorumlanmasina dayanan memnuniyet ya da memnuniyetsizlik deneyimi ile ilgilenmesidir. Bu bakımdan mutluluk, yalnızca fiziki hedonizme indirgenemeyen, farklı alanlardaki amaçlara ya da birey için değerli sonuçlara ulaşılmasından edinilebilen bir durumdur (Diener, Sapyta ve Suh, 1998). K1sacası, hedonik iyi oluşu ifade eden öznel iyi oluş yaklaşımına göre mutluluk bir kişinin bütün olarak hayatının öznel değerlendirmesini yansıtmaktadır (Diener, 1984). Waterman (1993), mutluluğun hedonik yaklaşımına karşın, 
eudaimonik yaklaşımın, insanları gerçek benliğine uygun olarak yaşamaya çağırdığın belirtmiştir. 'eu' (iyi) ve 'daimon' (ruh) kelimelerinin birleşiminden oluşan eudaimonia "mutluluk", "refah", "gelişme" anlamlarına gelmektedir. Ryff ve Keyes (1995) öznel iyi oluş yaklaşımından farklı olarak, iyi oluşa eudaimonik açıdan yaklaşan psikolojik iyi oluş kavramını ortaya atmış ve psikolojik iyi oluşun ölçümüne; özerklik, kişisel gelişim, öz-kabul, yaşam amacl, ustalık ve olumlu ilişkisellik olmak üzere kendini gerçekleştirmenin altı farklı yönünü ele alan çok boyutlu bir yaklaşım sunmuşlardır. Bu altı yapı psikolojik iyi oluşu, hem teorik hem de operasyonel olarak tanımlamakta ve duygusal ve fiziksel sağlığı arttıran faktörleri belirlemektedir (Ryff ve Singer, 1998).

Yurt dışında ve yurt içinde mutluluğun ölçümüne ilişkin çalışmalar incelendiğinde, genellikle araştırmaların mutluluk, öznel iyi oluş, psikolojik iyi oluş, pozitif-negatif duygulanım, yaşam doyumu ve mental iyi oluş kavramları üzerinde gerçekleştirildiği görülmektedir. Bu kavramların anlamları birbiriyle tamamen aynı olmamakla birlikte büyük oranda ilişkilidir; çünkü bu kavramların hepsi olumlu işlevselliği ve mutluluğu sağlayan koşullarla ilgilidir (Tuzgöl-Dost, 2005). Yurt içinde, mutluluk ile ilgili ölçme araçları daha çok uyarlama çalışmalarından oluşmaktadır. Uyarlanan ölçme araçlarına örnek olarak; Oxford Mutluluk Ölçeği (Hills ve Argyle, 2002; Doğan ve Sapmaz, 2012), Öznel Mutluluk Ölçeği (Lyubomirsky ve Lepper, 1999; Akın ve Satici, 2011), Yaşam Doyumu Ölçeği (Diener, Emmons, Larsen, ve Griffin, 1985; Köker, 1991), Pozitif ve Negatif Duygu Ölçeği (Watson, Clark, ve Tellegen, 1988; Gençöz, 2000), Psikolojik İyi Olma Ölçekleri (Ryff, 1989; Akın, 2008) ve Warwick-Edinburgh Mental İyi Oluş Ölçeği (Tennant vd., 2007; Keldal, 2015) verilebilir. Ayrıca, uyarlama çalışmalarının yanı sıra ölçek geliştirme çalışmalarına rastlanmaktadır. Öznel İyi Oluş Ölçeği (Tuzgöl-Dost, 2005), Mutluluk Ölçeği (Demirci, 2017), Ergen Öznel İyi Oluş Ölçeği (Eryılmaz, 2009) bunlardan bazılarıdır.

\section{Mutluluk Potansiyelinin Belirlenmesi}

Alan yazında, "durum" (state) ve "özellik" (trait) çoğu zaman iç içe geçen ve araştırmacılar tarafından tartışılan kavramlardır. En çok, öfke ve kaygı bağlamında tartışılan "durum" ve "özellik" kavramları son yıllarda iyimserlik, umut, yalnızlık ve mutluluk değişkenleri açısından incelenmektedir. Durum; 
fiziksel, davranışsal, bilişsel ve psikolojik tepkileri de içeren iç ve / veya dış tetikleyicilere anlık duygusal tepkidir. Duygulanmanın süresi ve yoğunluğu, uyarılma düzeyi, engellenme düzeyi, öznel algı, bağlam gibi çeşitli faktörlere bağlı olarak değişebilir. Duygusal tepki geçtikten sonra, 'normal' denge devam eder (Spielberger ve Sydeman, 1994), bu nedenle durum geçici bir duygusal değişim yaratır. Diğer taraftan "özellik", bireyin sürekli olarak belirli bir şekilde hissetme, düşünme ve davranma eğilimi gösteren istikrarlı bir duyguya işaret eder (Spielberger ve Sydeman, 1994). Alan yazında, mutluluğun sürekli bir özellik mi yoksa durum mu olduğu konusunda iki tartısma vardır. Bunlardan birisi, mutluluktaki farklılıkların kalıcilığına (özellik) odaklıdır ve mutluluktaki eşitsizlikleri azaltma şansı ile ilgilenir. Diğer görüş ise mutluluk düzeyinin değişkenliğine (durum) odaklıdır ve daha fazla mutluluk yaratma ihtimali ile ilgilenir (Veenhoven, 1998).

$\mathrm{Bu}$ araştırmanın konusunu oluşturan "mutluluk potansiyeli" kavramı, beklentilerinin üstünde bir bilgiyle karşılaşan kişilerin mutlu olduğu düşüncesinden yola çkarak; kişinin duygularını ifade etmesinin duygularını artıracağı, duygularını yaşamasının engellenmesinin ise rahatsız edici olduğu varsayımından hareketle araştırmacılar tarafından ortaya konmuştur. Kişinin içinde bulunduğu durumdan doyum sağlaması, sevinç duyması anlamına gelen mutluluk potansiyeli, mutluluk düzeyinin değişkenliğine (durumluk mutluluk) odaklıdır ve mutluluk yaratma ihtimali ile ilgilenir. Mutluluğun bilginin beklentiye oranı olarak ele alınması oldukça eskiden beri öne sürülmüştür. Örneğin Seneca mutluluğu arzu ile tatmin edilmiş arzu arasındaki oran olarak görmüştür (McMohan, 2006). Horatius da sahip olunanlar (elde edilen bilgi) ile sahip olunması gerekenlerin (elde etmeyi beklediği şeyler) insanı mutlu ettiğini söylemiştir (McMohan, 2006). Aynı düşünceyi tersinden ele alan Jean-Jacques Rousseau mutsuzluğun isteklerimizle yeteneklerimiz, başka bir deyişle beklentilerimizle sahip olduklarımız (bilgiler) arasındaki uyumsuzluktan ileri geldiğini belirtmiştir (Rousseau, 2009). Görüldüğü gibi, elde etmek istenenler, beklentiler ile sahip olunanlar, yani bilgiler arasındaki uyumun insanı mutlu ettiği düşüncesi tarih boyunca çeşitli şekillerde ele alınmıştır. Burada ele alınan mutluluk formülü bu iki düşüncenin bütünleştirilerek sistematik hale getirilmesine dayanmaktadır.

Mutluluk potansiyelinin bilgi, beklenti ve haz (davranış, ifade) olmak üzere üç alt boyutu vardır (McMohan, 2006; Rousseau, 2009; Thorndike, 1913; Vroom, 1964). Mutluluk potansiyelinde "beklenti" temel öğedir, çünkü 
mutlu olabilmek için bir beklenti içinde olmak gerekir. Beklenti Kuramı'nın temel varsayımlarından biri (Vroom, 1964), insanların, belirli bir davranışın arzulanan sonuçlara yol açacağına ilişkin beklenti derecesine dayanarak alternatif davranış planları arasında karar verdiği yönündedir. Vroom'a (1964) göre, "İnsanlar, hazzı artırma ve acıyı önleme arzusunun bir sonucu olarak algılara, tutumlara ve inançlara dayanan belirli bir eylem sürecini bilinçli olarak seçmektedirler." Bu görüş aynı zamanda, "insanların hoşa giden sonuçlara sahip davranışlarda bulunduğu ve hoş olmayan sonuçlara sahip davranışlardan kaçındığını belirten pekiştirme kuramının ilkelerinden biri" olarak etki yasasında görülmektedir (Thorndike, 1913). Mutluluk potansiyelinin diğer bir alt boyutu, beklentinin karşılanıp karşılanmadığı ile ilgili "bilgi" dir. Bilgi, bilen ile bilinen arasındaki ilişki olarak tanımlanabilir, ancak bu ilişki genellikle "kaynak" aracılığıyla kurulur. Bilişsel bilgi, dünya ve insan hakkında herkes tarafından kontrol edilmiş ve sınanabilir bilgiler sağlarken; yaşantısal bilgi, insanın özerklik duygusunu pekiştirir, meşgul olma güdüsünü doyurur (Bacanl1, 2015). Bilgi edinememek insanları tedirgin edip, stres yaşamasına neden olurken; bilginin gerçek olması mutluluğu gerçek kılar. Mutluluk potansiyelinin son alt boyutu ise "davranış"tır. Bilgi edinememek nasıl insanları tedirgin edip, stres yaşamasına neden oluyorsa mutluluğu yaşayamamak da rahatsız edicidir. Buna karşın mutluluğun yaşanması insanların mutluluğunu artıracaktır. Mutluluğun yaşanması; mevcut pozitif deneyimlere tamamen kendini bırakmak, pozitif olaylara duygusal tepkileri davranışsal olarak (örn. gülümseyerek) göstermek, pozitif deneyimleri başkalarıyla paylaşmak, bunlara şükretmek veya pozitif deneyimleri başkalarıyla kutlamak gibi bir dizi haz alma stratejisini içerir (Bryant ve Veroff, 2007). Mutluluk formülündeki haz ögesi hazzın insanın mutluluğundaki önemli bir öge olduğu fikrinden kaynaklanır. Fiziksel dünyanın yerçekimi kuvvetinin ruhsal dünyadaki karşılığının haz kuvveti olduğunu öne süren John Locke (1996), aslında buna işaret etmiştir. Locke insanların farklı şeylerden haz duyduklarını da vurgulamıştır. Ayrıca Locke'a (2002) göre mutluluk peşine düşülmesi gereken bir şeydir. İnsan haz duymaya çalışır. Kuşkusuz haz ilkesi Sigmund Freud için temel dayanaktır (Freud, 1999). Freud (1999) mutluluğun hazzı duyumsamak olduğunu belirtmiştir.

Pozitif psikoloji yaklaşımı, insanların, hayatın yaşamaya değer olduğuna inanmaya iten faktörleri ve yaşamda karşılaştıkları zorlukların üstesinden gelmelerine ve anlamlı yaşam deneyimleri yaratmalarına teşvik eden güçlü 
yönleri ortaya çıkarmaya çalışmaktadır (Seligman ve Csikszentmihalyi, 2000). Diğer bir ifadeyle, pozitif psikolojinin temel amac iyi oluşu anlamak ve artırmaktır. Bu çalışmanın amacı ise "mutluluk potansiyeli" kavramını ortaya koymak ve bu kavramı işlevsel hale getirmek için bir ölçme aracı geliştirmektir. Böylelikle, kişilerin bir durumda ne kadar mutlu olabileceklerini kestirebilmek mümkün olacaktır. Bu araştırma, beklenti, bilgi ve haz (davranış, ifade) alt boyutlarıyla "mutluluk potansiyeli" kavramının ortaya konması, ölçülebilir hale getirilmesi ve bir durumda ne kadar mutlu olunabileceğinin belirlenebilmesi açısından önem taşımaktadır. Ayrıca, bu çalışmanın, mutluluk ve mutluluk potansiyeli konusunda yapılacak sonraki araştırmalar için yol gösterici olacağı düşünülmektedir.

\section{Yöntem}

\section{Araştırma Grubu}

Mutluluk Potansiyeli Ölçeği'nin geliştirilmesi sürecinde internet üzerinden çevrimiçi ortamda kolay örnekleme yöntemine göre 306 katılımcıdan veri toplanmış, veri setine uygun olmadığı tespit edilen $28^{\prime}$ i veri setinden çıkarılarak açımlayıcı faktör analizi 278 (177 kadın, 101 erkek) katılımcı üzerinden yapılmıştır. Katılımcıların yaş aralığı 19-70 olup, yaş ortalaması 31.97'dır (SS: 10.288).

\section{Mutluluk Potansiyeli Ölçeği Geliştirme Süreci}

Ölçeğin geliştirilmesinde öncelikle üç boyutun (bilgi, beklenti, haz) açıklamaları hazırlanmıştır. Sonra bu üç boyutu temsil etmek üzere 25 maddelik bir deneme formu oluşturulmuştur. Ölçek 5'li dereceleme (1- Hiç, 2- Biraz, 3- Oldukça, 4-Çok, 5- Pek çok) şeklinde hazırlanmıştır. Formun oluşturulmasında psikolojik danışma ve rehberlik alanından üç uzmanın görüşleri alınmıştır.

Hazırlanan form online test uygulama sitelerinden birine yüklenmiş ve sosyal medya üzerinden katılım duyurusu yapılmıştır. 15 günlük bir süre içinde ilgili siteye giderek uygulamaya katılan kişilerin verileri toplanmıştır. Bu şekilde uygulama grubu 306 kişiden oluşmaktadır. Eksik ve yanlış uygulamalar ve uç değerler çıkarıldıktan sonra 278 kişi üzerinde değerlendirme yapılmıştır. 


\section{İşlem ve Veri Analizi}

Verilerin analizine geçmeden önce araştırmacılar tarafindan veri setleri yanlış veri girişi ve kayıp veriler için taranmış ve araştırma grubunda da belirtildiği gibi ilgili veri setinden çıkarılmıştır. Betimsel analizler ve açımlayıcı faktör analizinin gerçekleştirilmesinde SPSS 24 istatistik paket programından yararlanılmıştır. Ölçeğin geçerliği, yapı geçerliği ile incelenmiştir. Ölçeğin güvenirliği ise Cronbach Alfa güvenirlik katsayısı ile hesaplanmıştır.

\section{Bulgular}

\section{Mutluluk Potansiyeli Ölçeği'nin Geçerliğine İlişkin Bulgular}

Mutluluk Potansiyeli Ölçeği' nin geçerlik çalışmaları kapsamında 278 katılımcıdan elde edilen veriler üzerinde açımlayıcı faktör analizi yapılmıştır. Bunun için ilk olarak verilerin açımlayıc faktör analizine uygunluğu incelenmiştir. Açımlayıc faktör analizinde örneklem büyüklüğünün yeterliliğine ilişkin olarak en sık başvurulan teknik Kaiser-Meyer-Olkin (KMO) örneklem yeterliliği ölçüm tekniği gösterilebilir. KMO değeri 0 ile 1 arasında bir değer ortaya koymaktadır ve elde edilen değerin 1'e yaklaşması örneklem büyüklügünün yeterliliğine ilişkin fikir vermektedir (Seçer, 2015). Bu bağlamda analiz sonucunda KMO değeri (.89) ve Barlett bütünlük testi $(\mathrm{p}<.01)$ sonuçlarınn AFA için uygun olduğu anlaşılmıştır. Temel Bileşenler analizi tekniği kullanılan analiz sürecinde Scree Plot grafiğinin öngörülerinden hareketle araç, üç faktöre zorlanmış ve Direct Oblique döndürme yapılmıştır. Analiz sonucunda üç faktörün Mutluluk Potansiyeli Ölçeği'ne ait varyansın \% 64.86'sını açıkladığ1 görülmüştür (Tablo 1). Beklenti alt boyutu, faktör yükleri .616 ile .840 arasında değişen üç maddeden oluşmakta ve MPÖ'ye ait varyansın \% 12.13'ünü açıklamaktadır. Benzer şekilde bilgi alt boyutu, yükleri .567 ile .800 arasında değişen üç maddeden oluşmaktadır. Bu üç madde MPÖ'ye ait varyansın \% 9.53’ünü açıklamaktadır. Haz alt boyutu, faktör yükleri .752 ile .858 arasında değişen beş maddeden oluşmakta ve MPÖ'ye ait varyansın \%43.194'ünü açılamaktadır. Genel olarak bakıldığında, boyutlarda yer alan maddelerin faktör yüklerinin kabul edilen sınırların üzerinde olduğu ve açılanan varyansın tatminkâr düzeyde bulunduğu söylenebilir (Tablo 1). 
Tablo 1. Mutluluk Potansiyeli Ölçeği'nin Yapı Matrisi

\begin{tabular}{|c|c|c|c|}
\hline Maddeler & Beklenti & Bilgi & Haz \\
\hline 1. Beklediğim gibi olması benim için çok iyi olur. & .840 & & \\
\hline 7. Beklediğim gibi olması benim işlerimi kolaylaştırır. & .657 & & \\
\hline $\begin{array}{l}\text { 4. Beklediğim gibi olma ihtimali benim için diğer ihtimaller- } \\
\text { den daha önemli. }\end{array}$ & .616 & & \\
\hline $\begin{array}{l}\text { 3. Beklediğim gibi olduğunu bilsem kendime güvenim } \\
\text { artardı. }\end{array}$ & & .800 & \\
\hline $\begin{array}{l}\text { 5. Beklediğim gibi olduğunu bilsem birçok şeye karşı tavrım } \\
\text { değişirdi. }\end{array}$ & & .784 & \\
\hline $\begin{array}{l}\text { 2. Beklediğim gibi olduğunu bilmek benim için büyük bir } \\
\text { şans olurdu. }\end{array}$ & & .567 & \\
\hline 8. Beklediğim gibi olursa haykırırım / çı̆̆lık atarım. & & & .858 \\
\hline 10. Beklediğim gibi olursa oynamaya başlarım. & & & .854 \\
\hline 6. Beklediğim gibi olursa sevinçten ağlarım. & & & .808 \\
\hline 11. Beklediğim gibi olursa kendimi kaybederim. & & & .781 \\
\hline $\begin{array}{l}\text { 9. Beklediğim gibi olduğunu duyarsam, koşup haberi } \\
\text { getirene sarılırım. }\end{array}$ & & & .752 \\
\hline Varyansı Açılama Yüzdesi & 12.13 & 9.53 & .43 .19 \\
\hline
\end{tabular}

$N=278$

\section{Mutluluk Potansiyeli Ölçeği'nin Güvenirliğine İlişkin Bulgular}

Mutluluk Potansiyeli Ölçeği'nin güvenirlik çalışmaları kapsamında 278 katılımcıdan elde edilen veriler üzerinde aracın iç tutarlık katsayıları hesaplanmıştır. Ölçeğin Cronbach alfa değerleri davranış alt boyutu (5 madde) için .886 , beklenti alt boyutu ( 3 madde) için .654 , bilgi alt boyutu ( 3 madde) için .642 olarak hesaplanmıştır. Ölçme aracının tümü için hesaplanan Cronbach alfa değeri .866'dır.

\section{Tartışma ve Sonuç}

Mutluluk Potansiyeli Ölçeği'nin geçerlik ve güvenirlik çalışmalarından elde edilen bulgular, geliştirilen ölçme aracı ile bir durumun veya olayın kişiyi mutlu etme potansiyelini veya kişinin mutlu olma kapasitesini belirlemek amacıyla kullanılabileceğini ortaya koymaktadır. Mutluluk Potansiyeli Ölçeği, beklenti ( 3 madde), bilgi ( 3 madde) ve davranış ( 5 madde) alt boyutlarını içeren toplam 11 maddeden oluşmaktadır. Cevaplama sistemi her ifade için “(1) Hiç”, “(2) Biraz”, “(3) Oldukça”, “(4) Çok” ve “(5) Pek çok” olarak beşli 
Likert tipindedir. Ölçek maddelerinin tümü olumlu ifade şeklindedir. Ölçekten alınacak en yüksek puan 55, en düşük puan 11'dir. Yüksek puan mutluluk potansiyelinin yüksek olduğunun göstergesidir. Ölçekte üç alt boyut bulunsa da toplam puan alarak değerlendirme yapmak kişi için daha işlevseldir. Dolayısıyla ölçek cevaplandırıldığında toplam puan alınarak durumun kişiyi mutlu etme potansiyeli veya kişinin durumdan mutlu olma potansiyeli belirlenebilir. Bunu şu soruyla ifade etmek de mümkündür: "Bu durum kişiyi ne kadar mutlu edebilecek?" veya "Kişi bu duruma bağlı olarak ne kadar mutlu olabileceğini düşünüyor?". Yüksek puan, durumun bireyin mutlu etme potansiyelinin yüksek olduğunu, düşük puan bireyi mutlu etme potansiyelinin düşük olduğunu gösterir.

Mutluluk Potansiyeli Ölçeği'nin alt boyutları işleme sokularak, psikolojik danışma sürecinde de kullanılabilir. Kişinin kendisini mutlu etmesini beklediği durumu ifade eden beklenti alt ölçeğinde alınan puan düşükse ve hatta birkaç uygulama sonucunda hep düşük düzeyde kalıyorsa, kişiye hedef belirleme eğitimi verilmelidir. Bilgi alt ölçeği kişinin o beklentisinin gerçekleşmesi ile ilgili bilgi edinmesinin önemine işaret eder. Bilgi edinmenin farklı süreçleri vardır. Normal yollarla elde edilen bilgi kişinin beklentisi içindedir. Eğer kişinin bilgi potansiyeli düşük ve birkaç uygulamada düşük çıkmaya devam ediyorsa, bilgi öğesinin başka öğelerle desteklenmesi önerilebilir. Bunun en basit yolu kişinin beklemediği anda, yerde, kişiden bilgi edinmesidir. Ayrıca verilen bilginin sosyal destek, saygınlık, başarı, kazanç gibi öğelerle ilişkilendirilmesi bilginin kişi için değerini artırır. Davranış ölçeğinden elde edilen puan, kişinin mutluluğunu ne kadar yaşayabileceğini düşündügünün göstergesidir. Bu puanı düşük kişilere mutluluk eğitimi verilebilir ve davranışlarına nasıl yansıtabileceği ile ilgili öneriler ve uygulamalar yaptırılabilir. $\mathrm{Bu}$, aynı zamanda kendini ortaya koyma becerisinin (self-expression) geliştirilmesi demektir. Buradaki anlamiyla kendini ortaya koyma bir beceridir; dolayısıyla geliştirilebilir ve öğretilebilirdir. Diğer becerilerin bir kısmından farklı olarak mutlu olma becerisi bir kısırdöngü içerme ihtimali yüksek bir beceridir. Kişi beceremediğini düşündüğünde artık beceremediğini ve becerebilme olasılığının düşük olduğunu düşünmeye başlar. Bu bakımdan kişi bu beceriyi sürekli olarak göstermelidir, gösteremediği durumlar onda beceriksizlik duygusunu pekiştirebilir. Dolayısıyla bu durumda davranışçı tekniklerle becerebildiğinin gösterilmesi ve kişinin buna inanabilir hale getirilmesi önerilir. Bir bakıma bu sosyal beceridir, çünkü mutlu olmak kişiler için 
çoğunlukla sosyal yani başkalarının yanında gösterilebilen bir olaydır. Kişi için sosyal değerlendirilme ve onaylanma öğelerini de içinde taşır. Bu yüzden kişiler bir espriye başkalarıyla birlikteyken yalnız başına olduklarından daha çok gülerler. Bu özellikler dikkate alınarak kişilerin davranış gösterme potansiyelleri ölçülebilir ve geliştirilebilir. Durumluk mutlulukla ilgili olarak danışmada kullanılabilecek başka teknikler de vardır. Ancak onlar için ölçek kullanmak gerekmez; kişilere nasıl mutlu olabilecekleri ile ilgili başka önerilerde de bulunulabilir.

Sonuç olarak, Mutluluk Potansiyeli Ölçeği'nin bireylerin mutluluk potansiyellerini veya kapasitelerini ölçmede kullanılabilecek geçerli ve güvenilir bir ölçme aracı olduğu ve ölçeğin üç faktörlü bir yapıya sahip olmasına rağmen toplam puan üzerinden değerlendirilmesinin daha işlevsel olduğu söylenebilir. Bu çalışma, araştırmacıların bilgi, beklenti ve haz alt boyutları ile ortaya konan "mutluluk potansiyeli" kavramına dikkatlerini çekmek, kavramın ölçülebilir hale getirilmesi ve bir durumda ne kadar mutlu olunabileceğinin belirlenebilmesi açısından önem taşımaktadır. Çalışmanın yalnızca mutluluk araştırmalarına yön vermekle kalmayıp, bireysel ya da grupla psikolojik danışma süreçlerinde kullanılmasına da öncü olacağı düşünülmektedir. 


\title{
EXTENDED ABSTRACT
}

\section{The Potential for Happiness and Its Measurement \\ *}

\author{
Hasan Bacanl - Ayşe Sibel Demirtaş \\ Fatih Sultan Mehmet Vakıf University- Alanya Alaaddin Keykubat University
}

The Positive Psychology approach, grounded on the research about positive emotions and positive personality traits, is based on the idea that the scientific research (at the societal level) and the introduction of individual efforts (individual level) can promote the development of characteristics that encourage individuals to create meaningful life experiences (Seligman, 2002; Seligman, Steen, Park, and Peterson, Sheldon and Lucas, 2016). Since the emergence of a positive psychology approach, one of the most researched topics has been happiness. The emergence of positive psychology has raised the questions of religion, philosophy, economics and many other areas to answer the question of happiness: "What is happiness?", "How can we attain it?", "How can we maintain it once we have it?" (DeHaan and Ryan, 2014). There is a wide variety of definitions of happiness in the literature. For example, according to Veenhoven (1997), happiness is the mental state of a person's evaluation related to his/her whole life. Argyle and Crossland (1987) conceptualized happiness, including the frequency and degree of positive emotions, the average level of satisfaction in a given time period, and the absence of negative emotions such as depression and anxiety.

On the other hand, some researchers classify happiness as hedonic or eudaimonic. These approaches are largely attributed to the Greek philosophers, Aristippus and Aristotle, respectively. Hedonic well-being is defined as positive emotions and mental experiences that occur frequently, negative emotions and moods being rarely experienced, and a high level of life satisfaction (Diener, 1984). Psychologists who adopt a hedonic vision have focused on a broad understanding of hedonism, including the preferences and tastes of the mind and body (Kubovy, 1999). The dominant view among hedonic psychologists is that it deals with the experience of satisfaction or dissatisfaction, based on a broad interpretation of happiness, including subjective happiness 
and all judgments about the good / bad elements of life. In this respect, happiness is a situation that cannot be reduced to physical hedonism, but can be reached from achieving valuable results for different purposes or for individuals (Diener, Sapyta, and Suh, 1998). According to the subjective well-being approach, happiness reflects the subjective evaluation of a person's life as a whole. Waterman (1993) maintained that, in comparison with hedonic approach of happiness, the eudaimonic approach urges people to live in accordance with their true self. Eudaimonia, which is composed of the words "eu" = good and "daimon" = spirit means welfare, happiness, and flourishing focuses on how individuals struggle to demonstrate full functionality and gain awareness of their unique talents. The concept of psychological well-being was introduced by Ryff and Keyes (1995) which is different from the subjective well-being approach. The researchers presented a multi-dimensional approach to six different aspects of positive functioning: "self-acceptance", "personal growth", "purpose in life", "positive relations with others", "environmental mastery" and "autonomy". These six dimensions define psychological well-being both theoretically and operationally and determine the factors that increase emotional and physical health (Ryff and Singer 1998). The hedonic component, estimated through responses to questions such as "How happy are you right now?", and the eudaimonic component, based on responses to questions such as "How happy are you with your life in general?" ( Ryan and Deci, 2001; Gao, 2016 ). Ryan and Deci (2001) suggested that the focus of hedonic and eudaimonic are both lapping and distinct and that an understanding of well-being may be enhanced by measuring it in differentiated ways. Other researchers have conceptualized happiness as including three components: the frequency and degree of joy or positive affectivity, the average level of satisfaction over a period, and the absence of negative feelings, such as depression and anxiety (Argyle and Crossland, 1987).

When the studies related to the measurement of happiness in Turkey and abroad are examined, it is generally seen that the studies are carried out on the concepts of happiness, subjective well-being, psychological well-being, positive-negative affect, life satisfaction and mental well-being. Although the meanings of these concepts are not exactly the same, they are largely related; because all of these concepts are related to conditions that provide positive functionality and happiness (Tuzgöl-Dost, 2005). The measurement tools for happiness in Turkey generally consist of adaptation studies. The examples of 
measurements which has been adapted into Turkish Culture include; Oxford Happiness Scale (Hills and Argyle, 2002; adapted by Doğan and Sapmaz, 2012), Subjective Happiness Scale (Lyubomirsky and Lepper, 1999; adapted by Akın and Satici, 2011), Life Satisfaction Scale (Diener, Emmons, Larsen, and Griffin, 1985; adapted by Köker , 1991), Positive and Negative Affect Scale (Watson, Clark, and Tellegen, 1988; adapted by Gençöz, 2000), Psychological Well-being Scale (Ryff, 1989; adapted by Akın, 2008) and WarwickEdinburgh Mental Well-being Scale (Tennant et al., 2007; adapted by Keldal, 2015), Student Subjective Wellbeing Questionnaire (Renshaw et al., 2015; adapted by Renshaw and Arslan, 2016). In addition to the adaptation studies, there are scale development studies such as Subjective Well-Being Scale (Tuzgöl-Dost, 2005), Happiness Scale (Demirci, 2017), Adolescent Subjective Well-Being Scale (Eryılmaz, 2009)

In literature, state and trait are concepts that are often interrelated and discussed by the researchers. Most of the state and trait concepts discussed in the context of anger and anxiety are examined in terms of optimism, hope, loneliness and happiness in recent years. State is an immediate emotional response to internal and / or external triggers, including physical, behavioral, cognitive, and psychological responses. The duration and intensity of affect may vary depending on various factors, such as level of arousal, level of inhibition, subjective perception, and context. After the emotional reaction has been tolerated, the normal balance continues (Spielberger and Sydeman, 1994), thus the situation creates a temporary emotional change. On the other hand, the trait points to a steady feeling of an individual's tendency to feel, think and behave in a certain way (Spielberger and Sydeman, 1994). The literature review shows that there are two arguments about whether happiness is a trait or a state. One of them is focused on the permanence of the differences in happiness (trait) and deals with the chance to reduce inequalities in happiness. The other view is focused on the variability of the level of happiness and deals with the possibility of creating more happiness (state) (Veenhoven, 1998).

In the current study happiness has been conceptualized as a state to which we will refer as the potential for happiness. Based on the idea that people who are faced with information above their expectations are happier, we suggested that the expression of one's emotions would increase his / her emotions and the prevention of experiencing their feelings is disturbing. The potential 
for happiness which is the subject matter of this research (the capacity for happiness) is focused on the variability of the level of happiness (state happiness) and deals with the possibility of creating happiness. The potential for happiness can be defined as the degree of satisfaction or joy of the person in the situation. In the current study, we offered three sub-dimensions of the potential for happiness: expectation, knowledge and pleasure (expression). Expectation is the essential element of the potential for happiness; because it is necessary to have an expectation in order to be happy. One of the basic assumptions of Expectation Theory (Vroom, 1964) is that people decide between alternative behavior plans based on the degree of expectation that a particular behavior will lead to desired results. The theory asserts that the individual will decide to behave or act in a certain way because they are motivated to select a specific behavior over other behaviors due to what they expect the result of that selected behavior will be. This view is also seen in the law of effect as one of the principles of reinforcement theory, which indicates that people behave with pleasant results and avoid unpleasant behaviors (Thorndike, 1913). Second sub-dimension of the potential for happiness is knowledge about whether the expectation is met or not. Knowledge can be defined as the relationship between the knower and the known, but this relationship is usually established via the source. While cognitive knowledge provides the controlled and testable information that known by everyone about the world and human; experiential knowledge reinforces the sense of autonomy and satisfies the motivation of being engaged (Bacanl, 2015). While not being able to get knowledge makes people feel stressed; the fact that knowledge is real makes happiness real. The third sub-dimension of the potential for happiness is pleasure (expression). It is also uncomfortable for the individual when he / she is not able to experience happiness. Nevertheless, feeling of pleasure (expression) will increase the happiness of people. Pleasure or expression of happiness includes a series of strategies, including letting oneself go to the positive experiences, showing emotional responses to positive events (e.g., smiling), sharing positive experiences with others, giving thanks to them or celebrating positive experiences with others (Bryant and Veroff, 2007). Bryant and Veroff (2007) have proposed that savoring conceptualized as the capacity to attend to the joys, pleasures, and other positive feelings that we experience in our lives increases happiness. This model was substantiated in a study conducted by Jose, Lim and Bryant (2012) in which 
the relationships among and between positive life events, savoring, and positive mood states (happiness) are examined. Lyubomirsky and Layous (2013) also developed a positive-activity model which aims to explain how and why performing positive activities makes people happier based on theory and research suggest that people can increase their happiness through simple intentional positive activities, such as expressing gratitude or practicing kindness.

The positive psychology approach, which emphasizes the strengths of a person and maximizes human functionality, seeks to understand the factors affecting the development of individuals and communities for the discovery and promotion of human strengths (Sheldon et al., 2000). In other words, the main purpose of positive psychology is to understand and increase happiness. In the current study we aimed to suggest the concept of potential for happiness and to develop a measurement tool to make this concept functional. Thus, it will be possible to predict how happy people can be in a situation. The current research offers considerable contributions to positive psychology literature, as it draws attention of researchers to the potential for happiness concept with its three dimensions: expectation, knowledge and pleasure. Thus, the study has the potential to provide useful insight for further research and for experts working within the field.

A total of 306 individuals participated in the study; however 28 participants were excluded from the data set which are inappropriate for the analyses. The analyses were conducted with 278 observations, $63 \%$ females and $36 \%$ males aged between 19 and 70 years old $(M=31.97, S D=10.28)$. In the current research, convenience sampling method was used via online questionnaire. Convenience sampling refers to "choosing the nearest individuals to serve as respondents and continuing that process until the required sample size has been obtained or those who happen to be available and accessible at the time" (Cohen, Manion, and Marrison, 2011, p. 155).

In the process of the development of the scale, first, the explanations of three dimensions (expectation, knowledge and pleasure) were prepared. Then, a 25-item trial form was created to represent these three dimensions. Scoring was prepared using a 5-point Likert scale (1- None, 2- A little, 3Quite a bit 4- High, 5- Very high). The opinions of three experts whose professional is Psychological Counseling and Guidance were considered in the composition of the form. The prepared form has been uploaded to one of the 
online test application sites and announced via social media. Data were collected from people who participated in the study during a period of 15 days. In this way, the study group consists of 306 people. The analyses were conducted with 278 people after missing observations and outliers were excluded from the data set.

SPSS 24 statistical package program was used for descriptive analysis and exploratory factor analysis. The validity of the scale was examined with construct validity. The reliability of the scale was calculated by Cronbach's Alpha reliability coefficient.

Exploratory factor analysis was conducted on the data obtained from 278 participants within the scope of the validity studies of the Potential for Happiness Scale. For this purpose, first, the appropriate of the data for exploratory factor analysis was examined. In the exploratory factor analysis, the most frequently used technique for the adequacy of sample size is The Kaiser-MeyerOlkin (Kaiser, 1970). The Kaiser-Meyer-Olkin is the measure of sampling adequacy, which varies between 0 and 1 . The values closer to 1 are better and the value of 0.6 is the suggested minimum. In this context, $\mathrm{KMO}$ value (.89) and Barlett integrity test $(\mathrm{p}<.015)$ results were found to be suitable for exploratory factor analysis. Based on the predictions of the Scree Plot chart during the analysis process using the Basic Component analysis technique, the measure was forced into three factors and Direct Oblique rotation was performed. The results showed that three factors explained $64.86 \%$ of the variance in The Potential for Happiness Scale (Table 1). The expectation factor consisted of three items loads between .616 and .840, explaining $12.13 \%$ of the variance in The Potential for Happiness Scale. The knowledge factor consists of three items loads between .567 and .800 . These three items explain $9.53 \%$ of the variance in The Potential for Happiness Scale. Pleasure factor consists of five items loads between .752 and .858 and explains $43.194 \%$ of the variance in The Potential for Happiness Scale. In conclusion, it can be said that the factor loads of the items in the factors are above the accepted limits and the explained variance is satisfactory (Table 1). 
Table 1. Exploratory Factor Analysis of The Potential for Happiness Scale

\begin{tabular}{llll}
\hline Items & Factor 1 & Factor 2 & Factor 3 \\
\hline 1. It would be great for me that it was just as what I expected. & .840 & & \\
\hline 7. It makes my work easier if it is just as what I expect. & .657 & & \\
\hline $\begin{array}{l}\text { 4. The likelihood of what I expect is more important than any } \\
\text { other possibilities for me. }\end{array}$ & .616 & .800 & \\
\hline $\begin{array}{l}\text { 3. I would be more confident if I knew that it was just as what I } \\
\text { expected. }\end{array}$ & & .784 \\
\hline $\begin{array}{l}\text { 5. My attitude would change towards many things if I knew } \\
\text { that it was just as what I expected. }\end{array}$ & & .567 \\
\hline $\begin{array}{l}\text { 2. It would be a great chance for me to know that it was just as } \\
\text { I expected. }\end{array}$ & & .858 \\
\hline 8. I scream / shout if it is just as what I expect. & & .854 \\
\hline 10. I start to dance if it is just as what I expect. & & .808 \\
\hline 6. I cry with joy if it is just as what I expect. & & .781 \\
\hline 11. I lose myself if it is just as what I expect. & & .752 \\
\hline $\begin{array}{l}\text { 9. If I hear that it is just as what I expected, I will run and em- } \\
\text { brace the person who inform. }\end{array}$ & & 43.19 \\
\hline \begin{tabular}{l} 
Percentage of Variance Explained \\
\hline
\end{tabular}
\end{tabular}

The internal consistency coefficients of the scale were calculated on the data obtained from 278 participants within the scope of the reliability study of the Potential for Happiness Scale. The Cronbach's alpha values of the scale were calculated as .886 for pleasure factor (5 items), .654 for expectation factor (3 items) and .642 for knowledge factor ( 3 items). Cronbach's alpha value calculated for total scale is .866 .

\section{Kaynakça / References}

Akın, A. (2008). Psikolojik iyi olma ölçekleri: Geçerlik ve güvenirlik çalışması. Kuram ve Uygulamada Ĕ̆itim Bilimleri, 8(3), 721-750.

Akın, A., ve Satıcı, S. A. (2011). Öznel mutluluk ölçeği: Geçerlik ve güvenirlik çalışması. Sakarya Üniversitesi Eğitim Fakültesi Dergisi, 21, 65-77.

Argyle, M., ve Crossland, J. (1987). The dimensions of positive emotions. The British Journal of Social Psychology, 26(2), 127-37.

Bacanlı, H. (2015). Unde scis: Bilgi psikolojisi denemesi. İstanbul: Açlım Kitap.

Bryant, F., ve Veroff, J. (2007). Savoring: A new model of positive experience. Mahwah, NJ, US: Lawrence Erlbaum Associates Publishers. 
De Haan, C. ve Ryan, R. (2014). Symptoms of wellness: Happiness and eudaimonia from a Self-Determination Perspective. In K. M. Sheldon, \& R. E. Lucus (Eds.), Stability of happiness: Theories and evidence on whether happiness can change (p. 37-55). Amsterdam, Netherlands: Elsevier. doi: 10.1016/b978-0-12-411478-4.00003-

Demirci, İ. (2017). Huzurlu ve mutlu yaşamın değerler ve karakter güçleri bağlamında karma bir araştırmayla incelenmesi (Doktora tezi). Marmara Üniversitesi, Eğitim Bilimleri Enstitüsü, İstanbul.

Diener, E. (1984). Subjective well-being. Psychological Bulletin, 95(3), 542-75.

Diener, E., Emmons, R. A., Larsen, R. J., ve Griffin, S. (1985). The Satisfaction with Life Scale. Journal of Personality Assessment, 49(1), 71-75.

Diener, E., Sapyta, J. J., ve Suh, E. (1998) Subjective well-being is essential to wellbeing. Psychological Inquiry, 9(1), 33-37. doi: 10.1207/s15327965pli0901_3.

Doğan, T. ve Sapmaz, F. (2012). Oxford Mutluluk Ölçeği Türkçe Formunun psikometrik özelliklerinin üniversite öğrencilerinde incelenmesi. Düşünen Adam Psikiyatri ve Nörolojik Bilimler Dergisi, 25, 297-304.

Eryılmaz, A. (2009). Ergen Öznel İyi Oluş Ölçeği'nin geliştirilmesi. Türk Eğitim Bilimleri Dergisi, 7(4), 975-989.

Freud, S. (1999). Uygarlığın huzursuzluğu. (Çev. Haluk Barışcan). İstanbul: Metis Yayınları.

Gao, Y. (2016). The pursuit of happiness: Hedonic and eudaimonic well-being for intrinsically motivated agents ( Doctoral Dissertation). Retriewed from https://search.proquest.com/pqdtglobal/docview/1844397906/BE4499DB13474A47PQ/12?accountid=11054

Gençöz, T. (2000). Pozitif ve negatif duygu ölçeği: Geçerlik ve güvenirlik çalışması. Türk Psikoloji Dergisi, 15(46), 19-26.

Hills, P., ve Argyle, M. (2002). The Oxford Happiness Questionnaire: A compact scale for the measurement of psychological well-being. Personality and Individual Differences, 33, 1073-1082.

Jose, P. L., Lim, B. T., ve Bryant, F. B. (2012). Does savoring increase happiness? A daily diary study. The Journal of Positive Psychology, 7(3), 176-187. doi: 10.1080/17439760.2012.671345

Kaiser, H. (1970). A second-generation little jiffy. Psychometrika, 35, 401-415.

Keldal, G. (2015). Warwick-Edinburgh Mental İyi Oluş Ölçeği'nin Türkçe Formu: Geçerlik ve güvenirlik çalışması. The Journal of Happiness and Well-Being, 3(1), 103-115. 
Kubovy, M. (1999). On the pleasures of the mind. In D. Kahneman, E. Diener, and N. Schwarz (Eds.), Well-being: The foundations of hedonic psychology (pp. 134-154). New York, NY, US: Russell Sage Foundation.

Köker, S. (1991). Normal ve sorunlu ergenlerin yaşam doyumu düzeyinin karşılaştırılması. (Yayımlanmamış Yüksek Lisans Tezi). Ankara Üniversitesi, Sosyal Bilimler Enstitüsü, Ankara.

Locke, E. A. (2002). Setting goals for life and happiness. In C. R. Snyder, \& Shane J. Lopez (Eds), Handbook of positive psychology (pp. 299-312). New York: Oxford University Press.

Locke, J. (1996). Insan anlığı üzerine bir deneme. (Çev. Vehbî Hacıkadiroğlu). İstanbul: Kabalcı Yayınları.

Lyubomirsky, S., ve Layous, K. (2013). How do simple positive activities increase well-being? Current Directions in Psychological Science, 22(1) 57-62.

Lyubomirsky, S., ve Lepper, H. (1999). A measure of subjective happiness: Preliminary reliability and construct validation. Social Indicators Research, 46, 137-155.

McMahon, D. (2006). The pursuit of happiness. A history from the Greeks to the present. London: Allen Lane.

Renshaw, T. L., ve Arslan, G. (2016). Psychometric properties of the Student Subjective Wellbeing Questionnaire with Turkish Adolescents: A generalizability study. Canadian Journal of School Psychology, 31(2) 139-151. doi: 10.1177/0829573516634644.

Renshaw, T. L., Long, A. C. J., ve Cook, C. R. (2015). Assessing adolescents' positive psychological functioning at school: Development and validation of the Student Subjective Wellbeing Questionnaire. School Psychology Quarterly, 30, 534-552. doi:10.1037/spq0000088.

Rousseau, J. J. (2009). Emile (Çev. Yaşar Avunç). Türkiye İş Bankası Kültür Yayınları.

Ryff, C. D. (1989). Happiness is everything, or is it? Explorations on the meaning of psychological well-being. Journal of Personality and Social Psychology, 57, 1069-1081.

Ryff, C. D., ve Keyes, C. L. (1995). The structure of psychological well-being revisited. Journal of Personality and Social Psychology, 69(4), 719-727.

Ryff, C. D., ve Singer. B. (1998). The contours of positive human health. Psychological Inquiry, 9(1), 1-28. 
Ryan, R. M., ve Deci, E. L. (2001). On happiness and human potentials: A review of research on hedonic and eudaimonic well-being. Annual Review of Psychology, 52, 141-166.

Seligman, M. E. (2002). Authentic happiness: Using the new positive psychology' to realize your potential for lasting fulfillment. New York: Free Press.

Seligman, M. E. P., ve Csikszentmihalyi, M. (2000). Positive psychology: An introduction. American Psychologist, 55, 5-14.

Seligman, M. E. P., Steen, T. A., Park, N., ve Peterson, C. (2005). Positive psychology progress: Empirical validation of interventions. American Psychologist, 60(5), 410-421. doi: 10.1037/0003-066X.60.5.410.

Sheldon, K. M., ve Lucas, R. E. (2016). Stability of happiness: Theories and evidence on whether happiness can change. San Diego, CA, US: Elsevier Academic Press.

Spielberger, C. D., ve Sydeman, S. J. (1994). State-Trait Anxiety Inventory and State-Trait Anger Expression Inventory. In M. E. Maruish (Ed.), The use of psychological testing for treatment planning and outcome assessment (pp. 292-321). Hillsdale, NJ, US: Lawrence Erlbaum Associates, Inc.

Tennant, R., Hiller, L., Fishwick, R., Platt, S., Joseph, S., Weich, S., Parkinson, J., Secker, J. ve Stewart-Brown, S. (2007). The Warwick-Edinburgh Mental well-being scale (WEMWBS): Development and UK validation. Health and Quality of Life Outcomes, 5(1), 50-63. doi:10.1186/1477-7525-5-63.

Thorndike, E. L. (1913). Educational psychology: The psychology of learning. New York: Teachers College Press.

Tuzgöl-Dost, M. (2005). Öznel İyi Oluş Ölçeği'nin geliştirilmesi: Geçerlik ve güvenirlik çalışması. Türk Psikolojik Danışma ve Rehberlik Dergisi, 3(23), 103-111.

Waterman, A. S. (1993). Two conceptions of happiness: Contrasts of personal expressiveness (eudaimonia) and hedonic enjoyment. Journal of Personality and Social Psychology, 64(4), 678-691. doi: 10.1037/0022-3514.64.4.678.

Watson, D., Clark, L. A., ve Tellegen, A. (1988). Development and validation of brief measures of positive and negative affect: The PANAS scales. Journal of Personality and Social Psychology, 54(6), 1063-1070. doi:10.1037/00223514.54.6.1063.

Veenhoven, R. (1997). Quality-of-life in individualistic society: A comparison of 43 nations in the early 1990's. Social Indicators Research, 48, 57-86.

Veenhoven, R. (1998). Two state-trait discussions on happiness A reply to Stones et. al. Social Indicators Research, 43, 211-225.

Vroom, V. H. (1964). Work and motivation. New York: Wiley 


\section{Ek 1. Mutluluk Potansiyeli Ölçeği}

Açıklama: Yanıtlamaya başlamadan önce, gerçekleşmesini beklediğiniz olumlu veya olumsuz bir durumu veya olayı düşünmeniz gerekmektedir. Cevabınızı "Gerçekleşmesini beklediğiniz durum" kısmına yazınız (örn. sınavdan yüksek not almak). Kişisel bir durum ise "Özel" yazabilirsiniz. Yazmak istemediğinizde boş bırakabilirsiniz.

\begin{tabular}{|c|c|c|c|c|c|}
\hline \multicolumn{6}{|l|}{ Gerçekleşmesini beklediğiniz durum: } \\
\hline Maddeler & 岂 & ڤ્⿹ & 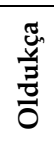 & ㄹ. & $\begin{array}{l}\breve{y} \\
\ddot{d} \\
\text { du }\end{array}$ \\
\hline \multicolumn{6}{|l|}{ 1. Beklediğim gibi olması benim için cok ivi olur. } \\
\hline \multicolumn{6}{|c|}{$\begin{array}{l}\text { 2. Beklediğim gibi olduğunu bilmek benim için büyük bir şans } \\
\text { olurdu. }\end{array}$} \\
\hline \multicolumn{6}{|c|}{ 3. Beklediğim gibi olduğunu bilsem kendime güvenim artardı. } \\
\hline \multicolumn{6}{|c|}{$\begin{array}{l}\text { 4. Beklediğim gibi olma ihtimali benim için diğer ihtimallerden } \\
\text { daha önemli. }\end{array}$} \\
\hline \multicolumn{6}{|c|}{$\begin{array}{l}\text { 5. Beklediğim gibi olduğunu bilsem birçok şeye karşı tavrım } \\
\text { değişirdi. }\end{array}$} \\
\hline \multicolumn{6}{|c|}{ 6. Beklediğim gibi olursa sevinçten ağlarım. } \\
\hline \multicolumn{6}{|l|}{ 7. Beklediğim gibi olması benim işlerimi kolaylaştırır. } \\
\hline \multicolumn{6}{|c|}{ 8. Beklediğim gibi olursa haykırırım / çığlık atarım. } \\
\hline \multicolumn{6}{|c|}{$\begin{array}{l}\text { 9. Beklediğim gibi olduğunu duyarsam, koşup haberi getirene } \\
\text { sarılırım. }\end{array}$} \\
\hline \multicolumn{6}{|c|}{ 10. Beklediğim gibi olursa oynamaya başlarım. } \\
\hline 11. Beklediğim gibi olursa kendimi kaybederim. & & & & & \\
\hline
\end{tabular}

\section{Kaynakça Bilgisi / Citation Information}

Bacanlı, H. ve Demirtaş, A. S. (2020). Mutluluk potansiyeli ve ölçülmesi. OPUS-Uluslararası Toplum Araştırmaları Dergisi, 15(10. Y1l Özel Say1s1), 4701-4722. DOI: 10.26466/opus.657215 